\title{
Mycosis Fungoides Presentation in Emergency
}

\author{
Asaad Shujaa*,1 and M. Owais Suriya $^{2}$
}

\section{Department of Emergency Medicine College of Medicine, King Khalid University Hospital, King Saud University, Ri- yadh, KSA}

\begin{abstract}
We present the case of a young lady who presented to the department of emergency medicine (DEM) for evaluation of painful breast swelling and skin indurations involving $90 \%$ of the body surface. She stayed long in the DEM for 3 days and managed for breast abscess she was consulted to dermatology for evaluation of skin lesions and preliminary diagnosed as rare skin T cell lymphoma. Final diagnosis based on clinical and histopathological was Mycosis Fungoids (MF).This case reveals that prompt referral from the DEM to the concerned speciality even for the rare type of diseases like MF can facilitate diagnosis and management and overall positive impact on disease outlook. Our patient was finally admitted under oncology unit and managed appropriately.
\end{abstract}

Keywords: Mycosis Fungoids, Cutaneous lymphoma, Tcell lymphoma, Breast swelling.

\section{INTRODUCTION}

MF is one of the adult types $\mathrm{T}$ cell lymphomas and is characterized by the localization of neoplastic T lymphocytes to the skin. These disorders present as a mixture of cutaneous manifestations with the abnormal proliferation of peripheral $\mathrm{T}$ cells. This condition must be distinguished from other types of cutaneous $\mathrm{T}$ cell lymphomas such as the Sezary syndrome, CD30+ T-cell lymphoproliferative disorders of the skin, Subcutaneous panniculitis-like T-cell lymphoma and others. Following case report, despite the rarity of condition, reflects that holistic approach in evaluating patient and prompt referral to respective speciality by DEM can play a important role in the management of the patient.

\section{CASE REPORT}

A 26 year old single female presented to the emergency department (ED) of King Khalid University Hospital, King Saud University, Riyadh KSA, complaining of painful swelling of her left breast and adjacent chest wall for few months reason for her presentation was increased frequency of pain for the week. She also reported swelling of the forehead and diffusely distributed rashes over her body for the same duration. She also gave history of fatigue, generalized body aches and joint pain. She reported regular menses and denied any anorexia, weight loss or accompanying fever. Her past medical history was unremarkable.

\section{EXAMINATION}

On the left side breast and surrounding soft tissues were swollen measuring $10 \times 10 \mathrm{~cm}$ with reddened, indurated skin and a purulent discharge. Another lesion of the same morphology was on her forehead; and this lesion measured $5 \mathrm{~cm}$ $\mathrm{x} 3 \mathrm{~cm}$. In addition to these lesions, there were scattered, patchy, areas of indurated skin involving approximately $90 \%$

*Address correspondence to this author at the Dept. of Emergency Medicine (65), King Khalid University Hospital, King Saud University, P.O. Box 7805, Riyadh- 11472, KSA; Tel: 009661 4699346; Fax: 009661 4672529; E-mail: asaads2003@yahoo.com of the body surface area (Fig. 1). Enlarged lymph nodes of the neck were noted bilaterally on both cervical chains; but no palpable lymph nodes were noted elsewhere. Her pulmonary, cardiovascular and neurological examinations were normal, whereas abdominal exam revealed an enlarged and palpable liver with a $16 \mathrm{~cm}$ span. The spleen was impalpable and no ascites.

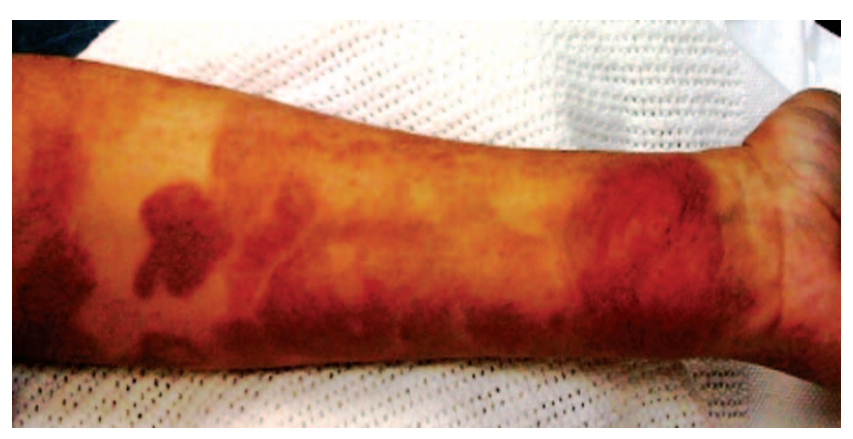

Fig. (1). Forearm with heterogeneous skin patches, plaques and erythrodermic lesions with brown pigmentation (poikiloderma).

In the DEM her workup was initiated. Samples of the purulent drainage from the chest lesion were sent for gram staining, culture and sensitivities. Intravenous ceftriaxone was administered empirically treat breast abcess. Laboratory testing demonstrated the following: WBC 10.8 thousand comprising $81 \%$ lymphocytes, Hgb $11.8 \mathrm{gm} / \mathrm{l}$, platelets $168,000 / \mathrm{L}$, urea $3.6 \mathrm{mmol} / \mathrm{L}$, creatinine $47 \mathrm{micromol} / \mathrm{L}, \mathrm{Na}$ $138 \mathrm{mmol} / \mathrm{L}, \mathrm{K} 4.0 \mathrm{mmol} / \mathrm{L}, \mathrm{Cl} 104 \mathrm{mmol} / \mathrm{L}$, total bilirubin $4.1 \mathrm{micromol} / \mathrm{L}$, total protein $71.6 \mathrm{~g} / \mathrm{L}$, albumin $35 \mathrm{gm} / \mathrm{L}$, alanine aminotransferase $430 \mathrm{u} / \mathrm{L}$, aspartate aminotransferase $33 \mathrm{u} / \mathrm{L}$, gamma-glutamyltransferase $45 \mathrm{u} / \mathrm{L}$, alkaline phosphatase $97 \mathrm{u} / \mathrm{L}$, Calcium $2.03 \mathrm{mmol} / \mathrm{L}$, lactate dehydrogenase $41.5 \mathrm{u} / \mathrm{L}$.

While in the DEM due to her features the possibility of occult underlying condition was suspected hence, the patient was referred to the dermatology service and after review a preliminary diagnosis of $\mathrm{T}$ cell lymphoma versus non- 
Hodgkin's lymphoma was made. The patient was admitted under dermatology for evaluation. She underwent radiological and histopathological evaluation. Ultrasound and computerized axial tomography (CAT) scan revealed enlarged cervical, axillary and inguinal lymph nodes; multiple thyroid

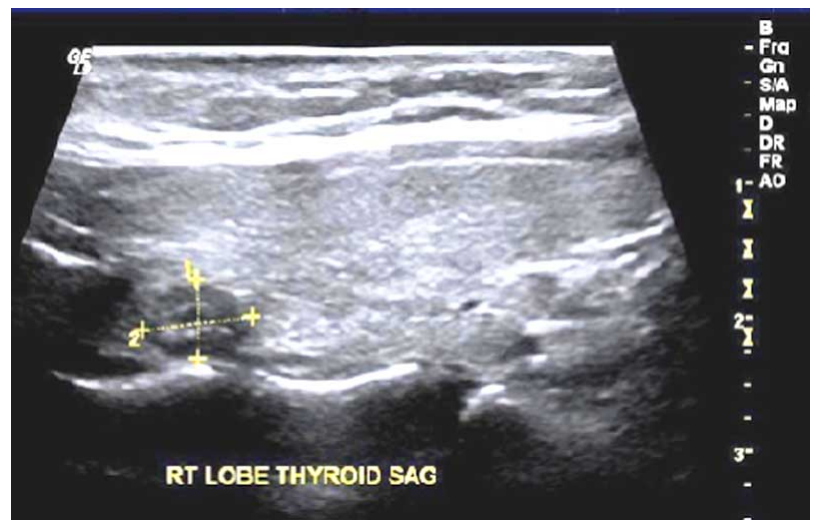

Fig. (2). Thyroid ultrasound showing well defined hypoechoic lymph nodes posterior to the right lobe of the thyroid gland.

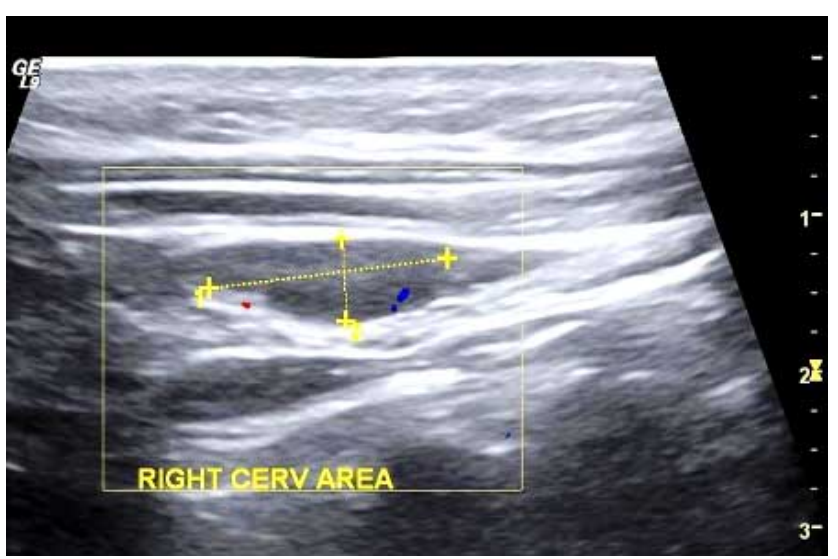

Fig. (3). Ultrasound of the neck showing an oval shaped hypoechoic cervical lymph node.

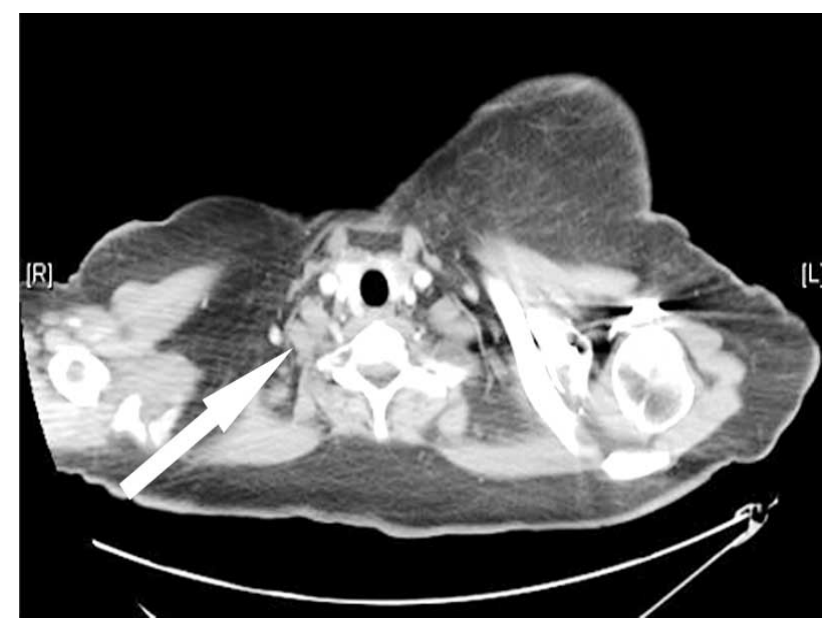

Fig. (4). CT image of the neck demonstrating large cervical lymph nodes on the right (arrow). and lung nodules, and thickened skin of the left lateral thoracic wall due to skin infiltration (Figs. 2-8). Her liver was enlarged at $18 \mathrm{~cm}$ and multiple small nodules were noted. Her skin biopsy showed perivascular, atypical mononuclear infiltrates into dermis forming aggregates. The atypical mononuclear cells were $\mathrm{CD} 4^{+\mathrm{ve}}$ and $\mathrm{CD} 8^{-\mathrm{ve}}$, a large number of cells were CD $30^{\text {+ve }}$ while $\mathrm{CD} 68^{+\mathrm{ve}}$ cells were present in intervening dermal histiocytes. These findings were confirmatory for $\mathrm{T}$ cell lymphoma/MF. Histopathology of biopsied lymph node demonstrated large $\mathrm{T}$ cells $\left(\mathrm{CD} 30^{+\mathrm{ve}}\right)$ consistent with blastic transformation of $\mathrm{T}$ cell lymphoma. A bone marrow biopsy showed no involvement.

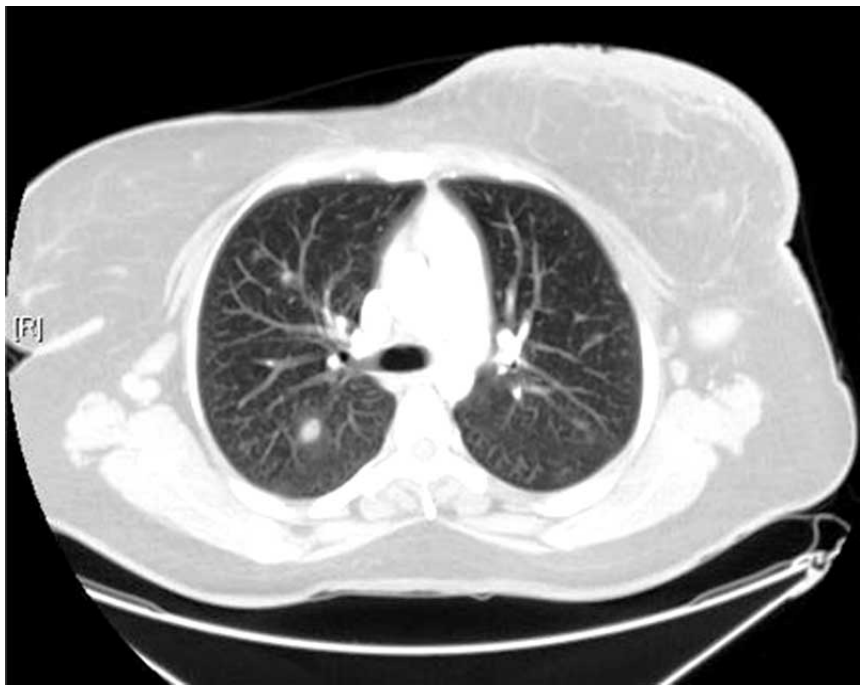

Fig. (5). CT axial image 1 of chest showing at level of arch of aorta multiple well defined lymph nodes in right lung of variable sizes.

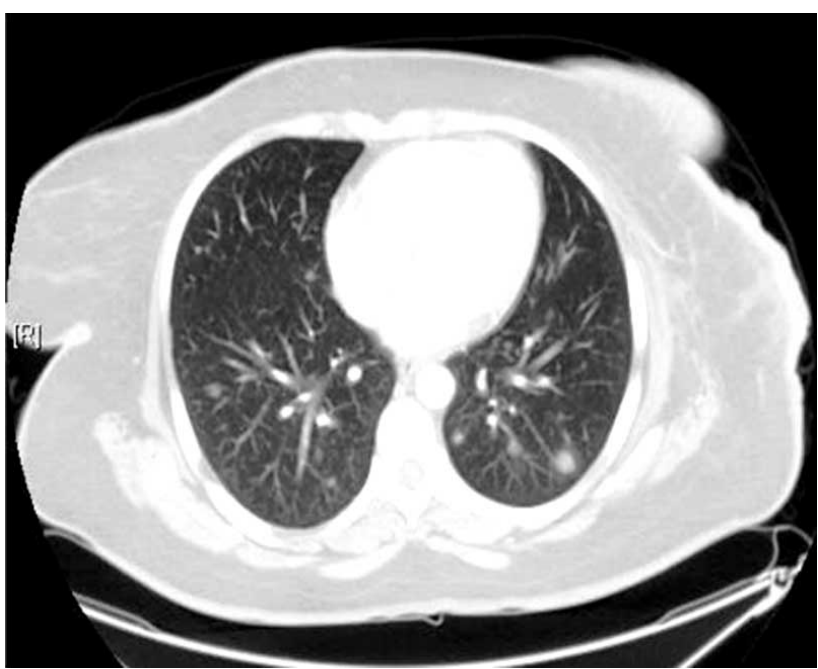

Fig. (6). CT axial image of chest showing multiple well defined and variably sized lymph nodes in both lungs at the level of the heart.

The patient was taken over by the Oncology unit and received chemotherapy in combination of Cyclophosphamide, Rituximab, Doxorubicin and Vincristine. 


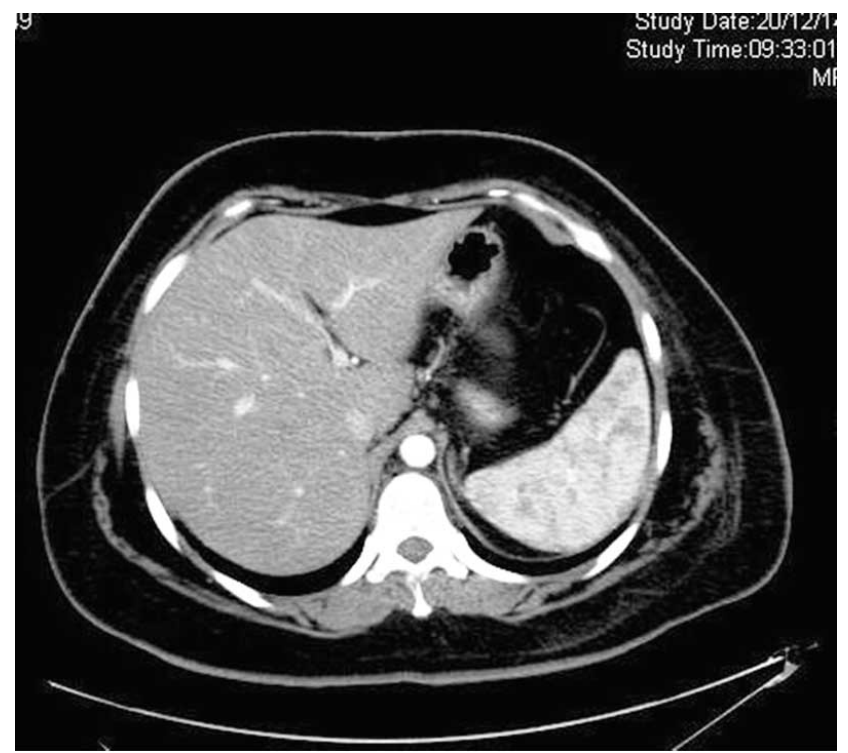

Fig. (7). CT axial image of the liver at gastrohepatic level showing well defined and variably sized lymph nodes.

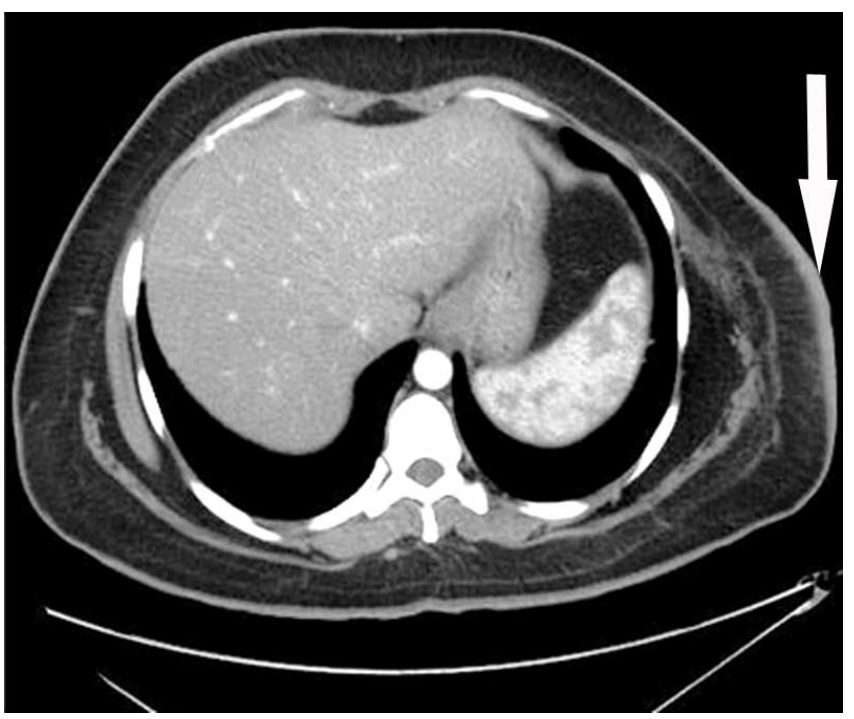

Fig. (8). CT axial image of the left lower chest showing left lateral chest wall thickening with thickening of the underlying muscles.

\section{DISCUSSION}

T cell lymphoma is an indolent non-Hodgkin lymphoma of T-cell origin and MF is a variant of $\mathrm{T}$ cell lymphoma with characteristic skin involvement. This disorder differs from other primary T-cell lymphomas by its own unique clinical features and histopathology [1,2].

MF has no definite etiology [3] but hypothetical genetic involvement $[4,5]$, chemicals and environmental exposure [6] human T cell virus type 1 (HTLV1) [7] and chromosomal abnormalities in the form of deletions and translocations have been implicated [8,9]. MF is a rare disease reported incidence is six cases per year per million [10]. The peak age of presentation is 55-60 years. Mycosis fungoids has a male to female ratio of $2: 1$ and is more common in black than white patients [11].

Skin lesions are the most common presenting features which include generalized patches, plaques, and erythroderma like features. The promyelocytic type is a prediagnostic manifestation of MF which may prolong for decades until rapid progression to advanced disease. In the promyelocytic phase skin lesions are often misdiagnosed as psoriasis and non specific dermatitis due its resemblance to these conditions. The rate of misdiagnosis is very common at this stage [12-14]. Another uncommon feature is the mottled skin pigmentation known as poikiloderma [15]. The skin lesions are typically multiple and often more than 5 centimeters in size. These lesions tend to increase in size with disease progression [16].

Extradermal manifestation can involve any part of the body but the organs commonly involved are lymph nodes, lungs, liver, spleen peripheral blood and bone marrow [1719].

Histopathologic hallmarks include epidermotropism or localization of abnormal T lymphocytes within the epidermis involving adhesion molecules soluble intercellular molecule 1 and 3 (sICAM1 and sICAM3). Aberrant cytokine production of helper $\mathrm{T}$ cells type 2 and low production of helper $\mathrm{T}$ cell type 1 cytokines are pathognomonic. This results in an impaired $\mathrm{T}$ cell response to mitogen which eventually leads to atypical progression of T cells [20-22].

The standard staging system for $\mathrm{MF}$ is based upon an evaluation of the skin $(\mathrm{T})$, lymph nodes $(\mathrm{N})$, visceral involvement (M), and blood (B). Therefore, the diagnostic strategy should include direct examination of the skin lesions followed by biopsy, complete blood count, blood chemistry, chest radiograph and computed tomography with or without positron emission tomography (PET). Molecular and immunohistopathologic studies are necessary to confirm the diagnosis in a patient with suspected skin lesions. The diagnostic criteria for MF is demonstrated in Table 1 [23]. The prognosis of patients with MF is variable. In those with extensive skin lesions and extradermal involvement the prognosis is poor. Treatment of MF depends upon the staging and includes localized topical therapy for early stages. The standard treatment of early lesions includes psoralens in association with UV-A irradiation (PUVA - psoralens and UVA), interferon $\alpha-2 \mathrm{a}$, retinoids, or a combination of these three modalities. Many new treatment protocols have been introduced for treatment of early MF including, among others, photodynamic therapy with 5-aminolaevulinic acid, new retinoids such as bexarotene. For advanced disease systemic retinoids, interferon, vorinostat, Denileukin, methotrexate, chlorambucil, and etoposide are also used in different combinations as per individual response. Bone marrow transplantation has also been used in certain cases. As a rule management of MF particularly in advance stage needs the specialized manage of a hematology-oncology service [24-26].

\section{CONCLUSION}

This case report demonstrates that the presentation of occult conditions in DEM is quite frequent, and in such encounters prompt and speciality focused consultations can facilitate early diagnosis and should be considered by DEM to play active role in improving health care system. 
Table 1. Diagnostic Criteria of Mycosis Fungoids*

\begin{tabular}{|c|c|}
\hline Criteria & Scoring \\
\hline $\begin{array}{l}\text { Clinical } \\
\text { Basic: } \\
\text { Persistent and/or progressive patches/thin plaques } \\
\text { 1. Non-sun exposed location } \\
\text { 2. Size/shape variation } \\
\text { 3. Poikiloderma }\end{array}$ & $\begin{array}{l}2 \text { points for basic criteria and two additional criteria } \\
1 \text { point for basic criteria and one additional criterion }\end{array}$ \\
\hline $\begin{array}{l}\text { Histopathological: } \\
\text { Basic: } \\
\text { Superficial lymphoid infiltrate } \\
\text { Additional: } \\
\text { 1. Epidermotropism without spongiosis } \\
\text { 2. Lymphoid atypia }\end{array}$ & $\begin{array}{l}2 \text { points for basic criteria and two additional criteria } \\
1 \text { point for basic criteria and one additional criterion }\end{array}$ \\
\hline $\begin{array}{l}\text { Molecular biology: } \\
\text { Clonal T cell receptor (TCR) gene rearrangement }\end{array}$ & 1 point for clonality \\
\hline $\begin{array}{l}\text { Immunopathologic: } \\
\text { 1. }<50 \text { percent } \mathrm{CD} 2+, \mathrm{CD} 3+\text {, and/or } \mathrm{CD} 5+\mathrm{T} \text {-cells } \\
\text { 2. }<10 \text { percent } \mathrm{CD} 7+\mathrm{T} \text { cells } \\
\text { 3. Epidermal/dermal discordance of } \mathrm{CD} 2, \mathrm{CD} 3, \mathrm{CD} 5, \text { or } \mathrm{CD} 7\end{array}$ & 1 point for one or more criteria \\
\hline
\end{tabular}

*A total of 4 points is required for the diagnosis of MF based on any combination of points from the clinical, histopathologic, molecular biological, and immunopathologic criteria. Adapted by ref. [23]: Pimpinelli, N, Olsen, EA, Santucci, M, et al., Defining early mycosis fungoides. J Am Acad Dermatol 2005; 53:1053.

\section{CONFLICT OF INTEREST}

None declared.

\section{ACKNOWLEDGEMENT}

None declared.

\section{REFERENCES}

[1] Siegel RS, Pandolfino T, Guitart J, et al. Primary cutaneous T-cell lymphoma: review and current concepts. J Clin Oncol 2000; 18(4): 2908-25.

[2] Jaffe ES, Harris NL, Stein H. World health organization classification of tumours: pathology and genetics of tumours of haematopoietic and lymphoid tissues. IARC Press: Lyon 2001.

[3] Whittaker S. Biological insights into the pathogenesis of cutaneous T-cell lymphomas (CTCL). Semin Oncol 2006; 33(1Suppl 3): S36.

[4] Van Doorn R, Zoutman WH, Dijkman R, et al. Epigenetic profiling of cutaneous T-cell lymphoma: promotor hypermethylation of multiple tumor suppressor genes including BCL7a, PTPRG, and p73. J Clin Oncol 2005; 23(17): 3886-96.

[5] Shin J, Monti S, Aires DJ, et al. Lesional gene expression profiling in cutaneous T-cell lymphoma reveals natural clusters associated with disease outcome. Blood 2007; 110(8): 3015-27.

[6] Whittemore AS, Holly EA, Lee IM, et al. Mycosis fungoides in relation to environmental exposures and immune response: a casecontrol study. J Natl Cancer Inst 1989; 81(20): 1560-7.

[7] Ghosh SK, Abrams JT, Terunuma H, et al. Human T-cell leukemia virus type I tax/rex DNA and RNA in cutaneous T-cell lymphoma. Blood 1994; 84(8): 2663-71.

[8] Thangavelu M, Finn WG, Yelavarthi KK, et al. Recurring structural chromosome abnormalities in peripheral blood lymphocytes of patients with mycosis fungoides/Sezary syndrome. Blood 1997; 89(9): 3371-7.

[9] Karenko L, Hyytinen E, Sarna S, et al. Chromosomal abnormalities in cutaneous T-cell lymphoma and in its premalignant conditions as detected by G-banding and interphase cytogenetic methods. J Invest Dermatol 1997; 108(1): 22-9.
[10] Criscione VD, Weinstock MA. Incidence of cutaneous T-cell lymphoma in the United States, 1973-2002. Arch Dermatol 2007; 143(7): 854-9.

[11] Bradford PT, Devesa SS, Anderson WF, et al. Cutaneous lymphoma incidence patterns in the United States: a population-based study of 3884 cases. Blood 2009; 113(21): 5064-73.

[12] Demierre MF, Gan S, Jones J, et al. Significant impact of cutaneous T-cell lymphoma on patients' quality of life: results of a 2005 National Cutaneous Lymphoma Foundation Survey. Cancer 2006; 107(10): 2504-11.

[13] Zackheim HS, Jones C, Leboit PE, et al. Lymphomatoid papulosis associated with mycosis fungoides: a study of 21 patients including analyses for clonality. J Am Acad Dermatol 2003; 49(4): 620-3.

[14] Zackheim HS, McCalmont TH. Mycosis fungoides: The great imitator. J Am Acad Dermatol 2002; 47(6): 914-8.

[15] Kodama K, Fink-Puches R, Massone C, et al. Papular mycosis fungoides: a new clinical variant of early mycosis fungoides. $\mathrm{J}$ Am Acad Dermatol 2005; 52(4): 694-8.

[16] Kim YH, Chow S, Varghese A, et al. Clinical characteristics and long-term outcome of patients with generalized patch and/or plaque (T2) Mycosis fungoides. Arch Dermatol 1999; 135(1): 26-32.

[17] Vonderheid EC, Diamond LW, Van Vloten WA, et al. Lymph node classification systems in cutaneous T-cell lymphoma. Evidence for the utility of the Working Formulation of Non-Hodgkin's Lymphomas for Clinical Usage. Cancer 1994; 73(1): 207-18.

[18] Baser S, Onn A, Lin E, et al. Pulmonary manifestations in patients with cutaneous T-cell lymphomas. Cancer 2007; 109(80): 1550-5.

[19] Hoppe RT, Wood GS, Abel EA. Mycosis fungoides and the Sezary syndrome: pathology, staging, and treatment. Curr Probl Cancer 1990; 14(60: 293-371.

[20] Epstein EH Jr, Levin DL, Croft JD Jr, et al. Mycosis fungoides. survival, prognostic features, response to therapy, and autopsy findings. Medicine (Baltimore) 1972; 51(1): 61-72.

[21] Girardi M, Heald PW, Wilson LD. The pathogenesis of Mycosis fungoides. N Engl J Med 2004; 350(19): 1978-88.

[22] Lopez-Lerma I, Estrach MT. A distinct profile of serum levels of soluble intercellular adhesion molecule-1 and intercellular adhesion molecule-3 in Mycosis fungoides and sezary syndrome. J Am Acad Dermatol 2009; 61(2): 263-70. 
[23] Pimpinelli N, Olsen EA, Santucci M, et al. Defining early Mycosis fungoides. J Am Acad Dermatol 2005; 53(6): 1053-63.

[24] Case DJ. Combination chemotherapy for Mycosis fungoides with cyclophosphamide, vincristine, methotrexate, and prednisone. Am J Clin Oncol 1984; 7(5): 453-555.

[25] Duarte RF, Schmitz N, Servitje O, et al. Haematopoietic stem cell transplantation for patients with primary cutaneous T-cell lymphoma. Bone Marrow Transplant 2008; 41(7): 597-604.
[26] Jones GW, Kacinski BM, Wilson LD, et al. Total skin electron radiation in the management of mycosis fungoides: Consensus of the european organization for research and treatment of cancer (EORTC) cutaneous lymphoma project group. J Am Acad Dermatol 2002; 47(3): 364-70.

(C) Shujaa and Suriya; Licensee Bentham Open.

This is an open access article licensed under the terms of the Creative Commons Attribution Non-Commercial License (http://creativecommons.org/licenses/by-nc/3.0/) which permits unrestricted, non-commercial use, distribution and reproduction in any medium, provided the work is properly cited. 